\title{
The Role of Exercise in Cancer Survivorship
}

\author{
Karen Y. Wonders \\ Wright State University, Maple Tree Cancer Alliance, Dayton, \\ United States of America
}

\section{Introduction}

At the turn of the $20^{\text {th }}$ century, the outlook was bleak for individuals diagnosed with cancer. The pathophysiology of cancer was not well understood, and the associated treatments were as dire as the disease itself. In 1971, President Nixon declared "war" on cancer (Haran \& DeVita, 2005). Since then we have seen dramatic improvements in cancer prognoses. At present, more than 11.7 million men and women are living as cancer survivors in the US, primarily due to early detection and advances in treatment options (Centers for Disease Control, 2007). However, such treatments often result in long-term physical and psychological toxicities, which negatively impact the cancer survivor's quality of life (QOL). These sequelae include, but are not limited to, decreased muscle strength, reduced cardiorespiratory fitness, reduced lean body mass, bone loss, fatigue (Pihkala et al., 1995; Lucia et al., 2003), depression, emotional distress, and anxiety (Jones et al., 2010). Thus, cancer research has shifted from its initial focus on prevention, to one that is centered on controlling or eliminating treatmentrelated toxicities with pharmacologic, physical, or social interventions. Now more than ever, healthy behavior choices are being promoted in attempt to limit this disease. In 2006, $42 \%$ of $\mathrm{NIH}$-funded research projects contained an intervention component designed to improve the psychosocial well-being, physical status, and/or health behaviors of cancer survivors (National Institutes of Health, 2011). One such intervention, exercise rehabilitation, has been widely reported in the literature to benefit cancer patients. With more than two decades of literature examining this topic, research continues to support a link between a physically active lifestyle and improvements in mental and physical QOL in cancer survivors (Douglas, 2005; Wiggins \& Simonavice, 2009). Thus, the primary aim of this chapter will be to explore the role of physical activity and exercise in cancer recovery.

\section{Precautions during exercise}

Cancer survivors often have disease or treatment-specific limitations that affect the exercise response. The specific effects of cancer on the exercise response are determined by the tissues affected and their level of involvement. Treatment-specific limitations arise from the type and duration of anticancer therapy employed. Surgery, chemotherapy, and radiation are the most common forms of cancer treatment, and all are associated with both acute and chronic effects that may negatively impact the exercise response. Table 1 briefly lists some of the more common treatment-related effects. In addition, most people are treated with a combination of surgery, radiation, and chemotherapy, which may cause a host of treatmentrelated problems. Pain, lymphedema, risk of infection, shortness of breath, neural deficits, 
fatigue, nausea and vomiting, cachexia, dehydration, and emotional distress are all common effects of cancer and its associated treatments on the patient's exercise tolerance.

\begin{tabular}{|l|l|}
\hline \multicolumn{1}{|c|}{ Cancer Treatment } & \multicolumn{1}{|c|}{ Potential Side Effects } \\
\hline Surgery & $\begin{array}{l}\text { Pain } \\
\text { Loss of flexibility }\end{array}$ \\
\hline Radiation & $\begin{array}{l}\text { Fatigue } \\
\text { Skin changes } \\
\text { Loss of flexibility } \\
\text { Cardiac and/or lung scaring }\end{array}$ \\
\hline Chemotherapy & $\begin{array}{l}\text { Anemia } \\
\text { Fatigue } \\
\text { Nausea } \\
\text { Myopathies } \\
\text { Neuropathies } \\
\text { Muscle weakness } \\
\text { Wasting } \\
\text { Changes in body composition that influence } \\
\text { gait and balance. }\end{array}$ \\
\hline
\end{tabular}

Table 1. Potential Side Effects of Anticancer Therapy (Swartz, 2009).

\subsection{Pain}

Depending on the specific location of the cancer, patients may experience high levels of pain. A tumor often causes pain, particularly when it involves the musculoskeletal system, causing it to press on bones, nerves, or body organs. In addition, chronic pain is frequently reported following surgery, often when large amounts of healthy tissue are removed along with cancer tissue. Chemotherapy and radiation treatments may also cause pain resulting from such side effects as peripheral neuropathy, mucositis, and radiation injuries (American Cancer Society, 2011). In most situations, physicians can prescribe medications to alleviate pain; however the intensity, type, duration, and frequency of exercise may need to be adjusted until the pain is brought under control.

\subsection{Lymphedema}

Lymphedema is a swelling that results from a blockage of the lymph vessels that drain fluid from tissues. It is commonly caused by a mastectomy or the removal of underarm lymph nodes during breast cancer surgery, and is experienced by approximately $10-15 \%$ of breast cancer patients (Muss, 2007). It is characterized by a persistent swelling, typically of the arm or leg. Often, patients may be treated with compression bandages to limit swelling. It is advised that exercises be carefully designed, so as not to increase the swelling or cause infection (Kercher et al., 2008).

\subsection{Risk of infection}

Chemotherapy, radiation, and immunotherapy often have a substantial impact on white blood cell count. Consequently, immune function often weakens during cancer treatment. 
Patients with very low blood counts are advised to avoid exercise all together, as they are at an increased risk for anemia. Frequent hand washing is advised, particularly in fitness centers, where germ count tends to be very high.

\subsection{Shortness of breath}

Shortness of breath is common when cancer has affected the lungs. It also may result when the bone marrow is affected, causing low red blood cell counts. Red blood cells carry oxygen throughout the body. Their ability to carry oxygen is measured by the amount of hemoglobin present in the blood. A low level of hemoglobin is indicative of anemia. With anemia, the body must work harder to supply oxygen to the tissues, causing the patient to feel fatigued and short of breath. Thus, anemic patients often have a limited aerobic performance because of the reduced oxygen-carrying capacity (Swartz, 2009).

\subsection{Neural deficits}

Neural deficits are common when tumors involve the central nervous system and brain. Problems with neural repair and decreased neurotransmitter activity may also arise as a side effect of anticancer therapy, related to the ability of chemotherapy to cross the blood-brain barrier and cause DNA damage and shortened telomere length (Klein, 2009). Neurological deficits can impact memory and emotion in cancer patients and may influence their motivation to adhere to an exercise program.

\subsection{Fatigue}

Fatigue is the most frequently reported symptom of cancer treatment (Schneider et al., 2003), affecting up to $96 \%$ of patients (Douglas, 2005). It is a whole-body tiredness that interferes with normal functioning and leaves the patient feeling irritable and unmotivated. Chronic fatigue has a negative impact on activities of daily life, social reintegration, and overall quality of life (Hartvig et al., 2006). In some patients, this fatigue is so debilitating to the individual that treatment must be discontinued or limited (Schneider et al., 2003).

\subsection{Nausea and vomiting}

Nausea, vomiting, and diarrhea are common effects of radiation and chemotherapy, leaving the patient feeling weak and at risk for electrolyte imbalances and dehydration. Cancer patients should avoid exercise for 24-hours after bouts of vomiting and diarrhea (YoungMcCaughan, 2006). As a result, it is important that exercise schedules be flexible to accommodate these bouts of irritation. Research indicates that in some instances, exercise will reduce feelings of nausea. However, if nausea persists upon initiation of exercise, activity should be stopped (Young-McCaughan, 2006).

\subsection{Cachexia}

Cachexia is a physical wasting syndrome accompanied by loss of muscle mass, fat mass, overall weight, and appetite. It affects up to $75 \%$ of cancer patients, especially those who are in the advanced stages of pancreas, esophagus, and stomach cancer. It is a metabolic disturbance that can result in electrolyte imbalances, weakness, fatigue, and reduced strength. Often, treatment with nutrient supplementation is ineffective (Martingnoni et al., 2003). Patients suffering from cachexia often lack the energy to exercise, so little is known about the impact of exercise on this condition. 


\subsection{Dehydration}

Dehydration is often experienced during chemotherapy, either as a side effect of frequent vomiting and diarrhea, or as a direct effect on the kidneys. Large quantities of water are necessary to help the kidneys filter chemotherapy medication. Fatigue and dizziness are symptoms of dehydration, both of which will impact the exercise response. It is important to ensure adequate fluid intake before, during, and after each exercise session.

\subsection{Emotional distress}

Cancer survivors will face a multitude of emotions as they battle cancer, creating a strain on interpersonal relationships. These emotions may include anger, depression, anxiety, and elation. This emotional distress can significantly impact a cancer patient's desire to participate in an exercise program.

\section{Benefits of exercise}

\subsection{Risk factors}

Not all risk factors that predispose an individual to cancer can be controlled (i.e., age, gender, race, genetic factors). However, healthy behaviors and lifestyle choices, along with environmental exposure risk reduction, can help reduce cancer development. Fifty to $75 \%$ of cancer deaths in the US are related to risk factors such as smoking, poor dietary choices, and physical inactivity (National Cancer Institute, 2009). Specifically, obesity and physical inactivity are associated with approximately $25-30 \%$ of colon, breast, endometrial, kidney, and esophageal cancers in the US (National Cancer Institute, 2009). The World Health Organization lists physical activity among the nine modifiable risk factors for cancer (World Health Organization, 2009). In addition, recent research supports the assertion that physical activity helps to prevent certain forms of cancer (Kruk, 2007; Miles, 2007), including cancer of the colon (Courneya \& Friedenreich, 2007), breast (Courneya \& Friedenreich, 2007), endometrium (Courneya \& Friedenreich, 2007), prostate (Courneya \& Friedenreich, 2007; Friedenreich \& Orenstein, 2002), lung (Courneya \& Friedenreich, 2007; Friedenreich \& Orenstein, 2002), kidney (Friedenreich \& Orenstein, 2002), rectus (Friedenreich \& Orenstein, 2002), and esophagus (Friedenreich \& Orenstein, 2002) cancer. The average risk reduction for each of these cancers varies from approximately 10-40\% (Wiggins \& Simonavice, 2010). Moderate physical activity ( $>4.5$ METs) appears to be associated with a greater protective effect than activities of lower intensity (Lee, 2003).

\subsubsection{Cancer survivorship}

In addition to reducing the risk of developing certain forms of cancer, physical activity has also been suggested to increase cancer survivorship by decreasing the risk of cancer recurrence, slowing the progression of cancer, and reducing the risk of secondary lifethreatening diseases (Courneya \& Friedenreich, 2007; Holmes et al., 2005; Haydon et al., 2005). One investigation (Holmes et al., 2005), revealed a reduction of $26-40 \%$ in the relative risk of breast cancer-related death and recurrence among the most active women compared with the least active. Similarly, higher levels of physical activity pre- and post-diagnosis of colon cancer and post-diagnosis of colorectal cancer were associated with a decrease in cancer-related mortality (Haydon et al., 2006; Meyerhardt et al., 2006a, 2006b). As such, the American Cancer Society recommends that exercise serve as an important part of an individual's cancer care plan, asserting that exercise will decrease feelings of fatigue both 
during and after treatment, and improve an individual's feeling of control and hope (American Cancer Society, 2011). In addition, the 2008 US Department of Health and Human Services (US DHHS) Physical Activity Guidelines for Americans indicate that individuals with chronic conditions, such as cancer, should be "as physically active as their abilities and conditions allow" (Physical Activities Guidelines Advisory Committee, 2008).

\subsection{General health benefits of exercise}

The general health benefits associated with participating in an exercise program are numerous, and include: improved cardiac output, increased ventilation; improved flexibility and range of motion; increased muscular strength and endurance; decreased resting heart rate; improved stroke volume, vasodilation, perfusion; improved metabolic efficiency; and improved blood counts (Wilmore et al., 2008). Likewise, there are several positive physiological and psychological changes for cancer survivors associated with moderate levels of physical activity and structured exercise.

\subsubsection{Aerobic capacity}

Research indicates that individuals being treated for cancer have the potential to significantly increase their aerobic capacity by engaging both home-based and structured exercise programs. Young-McCaughan et al (2003) reported an increase in $\mathrm{VO}_{2 \max }$ in cancer survivors following a 12-week exercise program. Thorsen et al (2005) found a significant increase in $\mathrm{VO}_{2 \max }$ for cancer survivors following a 14-week home training program. Wiggins and Simonavice (2008) reported an increase in $\mathrm{VO}_{2 \max }$ in breast cancer survivors after 3 months of resistance and aerobic training. Improvements in $\mathrm{VO}_{2 m a x}$ will enhance heart and lung functioning, thereby promoting healthy a blood pressure, blood volume, and gas exchange (Swartz, 2009). In addition, beneficial effects on energy balance, body mass, intestinal transit time, hormone concentrations, and antioxidant enzyme levels have been observed following improvements in aerobic capacity. Research also indicates an inverse relationship between fatigue and aerobic capacity, in that the higher an individual's aerobic capacity, the lower their levels of fatigue, which translates into a positive influence on QOL (DeVita et al., 2008).

\subsubsection{Muscular strength and endurance}

Several studies report improvements in muscular strength and endurance as a result of participating in an exercise program. In one study, muscular strength increased by approximately $41 \%$ in patients who participated in a 6-week resistance training program (Quist et al., 2006). Likewise, a 12-month exercise program resulted in increases in upper body muscular strength and lower body endurance in breast cancer survivors (Wiggins \& Simonavice, 2008). Finally, Cheema and Gual (2006) reported improvements in upper and lower body muscular endurance in previously trained breast cancer survivors following an 8-week exercise program. Increased levels of muscular strength and endurance have a positive effect on body composition, and is therefore associated with lower cancer mortality risk (American Heart Association, 2011).

\subsubsection{Psychosocial measures}

A favorable link between exercise and fatigue, psychosocial measures, and QOL has been reported in the literature. Historically, rest was the most common medical advice given for 
the treatment of fatigue (Courneya et al., 2000; Coon \& Coleman, 2004; Meyerowitz et al., 1983). Unfortunately, this can lead to even more fatigue (Schneider et al., 2003), as well as to aerobic de-conditioning and a lower functional capacity (Courneya et al., 2005). Conversely, several investigations have found that exercise is beneficial in reducing the fatigue experienced by individuals undergoing cancer treatment (Dimeo et al., 1996; Mock et al., 2007; Schwartz et al., 2001; Segal et al., 2001). In general, fatigue tends to subside within the first 5-10 minutes of activity. In terms of long-term improvement, research indicates that regular aerobic exercise over a period of 6 months improved endurance in breast cancer survivors (Damush et al., 2005) and decreased fatigue in patients with prostate and Hodgkin Disease (Watson \& Mock, 2004).

Improvements in QOL (Wiggins \& Simonavice, 2008, 2009; Courneya et al., 2009), anxiety (Courneya et al., 2003, 2000), depression (Courneya et al., 2003, 2000; Pirl \& Roth, 1999), body image (Pinto et al., 2003), immune function (Galvo \& Newton, 2005), and emotional well-being (Courneya et al., 2003) have also been reported following structured exercise programs. This holds true, even when cancer treatment has failed. It is believed that feelings of self-confidence and hope are directly related to the restored energy levels obtained through improved cardiorespiratory functioning. In addition, chronic exercise leads to a reduction in obesity and improved gastrointestinal functioning, both of which improve selfimage and overall outlook on life (Harriss et al., 2007).

\subsubsection{Cancer-specific benefits}

A concern with cancer survivors is that they often have comorbid conditions that will influence exercise prescription and management. More often than not, these comorbidities result from the very medications that are used to fight cancer. The good news, however, is that in most cases, exercise has been found to exert a positive effect on these toxicities. An outline of some of these conditions and the associated benefits of exercise is presented in Table 2. It should be noted that, for these adverse effects of cancer treatment, there may be predisposing factors which will influence the severity of the treatment effects.

\section{Components of an exercise program}

As demonstrated above, exercise is safe and effective both during and after most types of cancer treatment, and should therefore be included as an integral part of an individual's cancer care plan. The American Cancer Society recommends that exercise be part of a continuum of cancer survival care, spanning from treatment to recovery, as well as after-recovery maintenance and living-with-advanced-cancer (Doyle et al., 2006). At present, exercise and cancer recovery programs specifically designed for survivors are being implemented all over the country. The following protocols for exercise training with cancer patients are those employed by the Maple Tree Cancer Alliance ${ }^{\circledR}\left(\mathrm{MTCA}^{\circledR}\right)$, a cancer rehabilitation center in southwest Ohio dedicated to improving the quality of life of individuals afflicted with cancer by focusing on their physical and spiritual needs. All procedures used by MTCA $^{\circledR}$ follow the guidelines set forth by the American College of Sports Medicine (ACSM). Typically, the training sessions resemble that of a general exercise program, in that they often involve an aerobic component, resistance training, and flexibility exercises. However, given the unique challenges imposed by working with cancer survivors, ACSM recommends that fitness professionals working with cancer patients obtain a specialized training certification prior to training this group of individuals (Schneider \& Carter, 2003). 


\begin{tabular}{|l|l|}
\hline \multicolumn{1}{|c|}{ Cancer Treatment Toxicity } & \multicolumn{1}{|c|}{ Effect of Exercise } \\
\hline $\begin{array}{l}\text { Muscular Degeneration: } \\
\text { dancer treatments damage muscle tissue. Muscle may be severe enough to cause weakness and } \\
\text { fatigue. }\end{array}$ & $\begin{array}{l}\text { Exercise increases the integrity of } \\
\text { muscle tissue and protein } \\
\text { synthesis, stimulates the release } \\
\text { of numerous hormones that } \\
\text { increase muscle cell growth and } \\
\text { development, and improves } \\
\text { metabolism (DeVita et al., 2001; } \\
\text { Fischer et al., 2003). }\end{array}$ \\
\hline $\begin{array}{l}\text { Neurotoxicity: } \\
\text { Cancer treatments cause a decrease in motor function. } \\
\text { Exercise can enhance motor unit } \\
\text { recruitment and improve } \\
\text { neurochemical availability at the } \\
\text { cellular and tissue levels (Fischer } \\
\text { et al., 2003; Snyder, 1986). }\end{array}$ \\
\hline $\begin{array}{l}\text { Cardiotoxicity: } \\
\text { Cancer treatments cause: decreased left ventricular } \\
\text { dysfunction, reduced ejection fraction, diminished } \\
\text { contractility, reduced cardiac output and stroke } \\
\text { tissues }\end{array}$ & $\begin{array}{l}\text { Exercise can improve } \\
\text { cardiovascular efficiency by } \\
\text { strengthening the myocardium, } \\
\text { increasing cardiac output and } \\
\text { stroke volume, and decreasing } \\
\text { resting heart rate and lowering } \\
\text { exercise heart rate (DeVita et al., } \\
\text { 2001; Fischer et al., 2003). }\end{array}$ \\
\hline $\begin{array}{l}\text { Pulmonary Toxicity: } \\
\text { Cancer treatments cause a disruption in the structural } \\
\text { integrity of the airways }\end{array}$ & $\begin{array}{l}\text { Exercise can improve ventilation } \\
\text { and transport of oxygen from the } \\
\text { environment to the cellular level } \\
\text { (Chabner \& Longo 2010; Wilson, } \\
\text { 1978). }\end{array}$ \\
\hline
\end{tabular}

Table 2. Persistent Effects of Cancer Treatments Relative to Exercise Training.

\subsection{Phase 1: Exercise during treatment}

The following procedures will assist the fitness trainer to design a safe and effective exercise program for patients who are currently undergoing cancer treatment.

\subsubsection{Prescreening}

Given that cancer survivors often have limitations that pose challenges to exercise, it is necessary that the exercise intervention be individualized according to the needs of each patient. Current health status, cancer treatments, and anticipated disease trajectory must all be taken into consideration by the fitness trainer before designing an exercise program (Schmitz et al., 2010). Therefore, it is important that fitness professionals work closely with physicians and understand the specifics of the cancer survivor's diagnosis and treatments received, including existing health conditions and fitness level prior to cancer diagnosis. This is best obtained through comprehensive prescreening paperwork, which should include information regarding health history, cancer history, and psychological status, along with a medical examination and physician referral (Schneider et al., 2003). 


\subsubsection{Fitness assessment}

Once the prescreening paperwork is completed and reviewed, the patient's current level of fitness should be evaluated through a comprehensive fitness assessment. A comprehensive fitness assessment is one that measures body composition, cardiorespiratory fitness, muscular strength and endurance, flexibility, balance, and range of motion. Specifically, ACSM recommends a graded treadmill or bicycle ergometer test to assess cardiovascular function, a spirometer test for pulmonary function, dumbbells or resistance machines for muscular strength and endurance tests, and the modified sit and reach for flexibility assessment (Schneider \& Carter, 2003). In most cases, cancer patients can tolerate the standardized assessment protocols (Swartz, 2009); however, adaptations for certain exercise tests may be necessary if the patient has limited mobility or impaired functioning. Pictures of standard assessments are shown below (Figures 1-5).

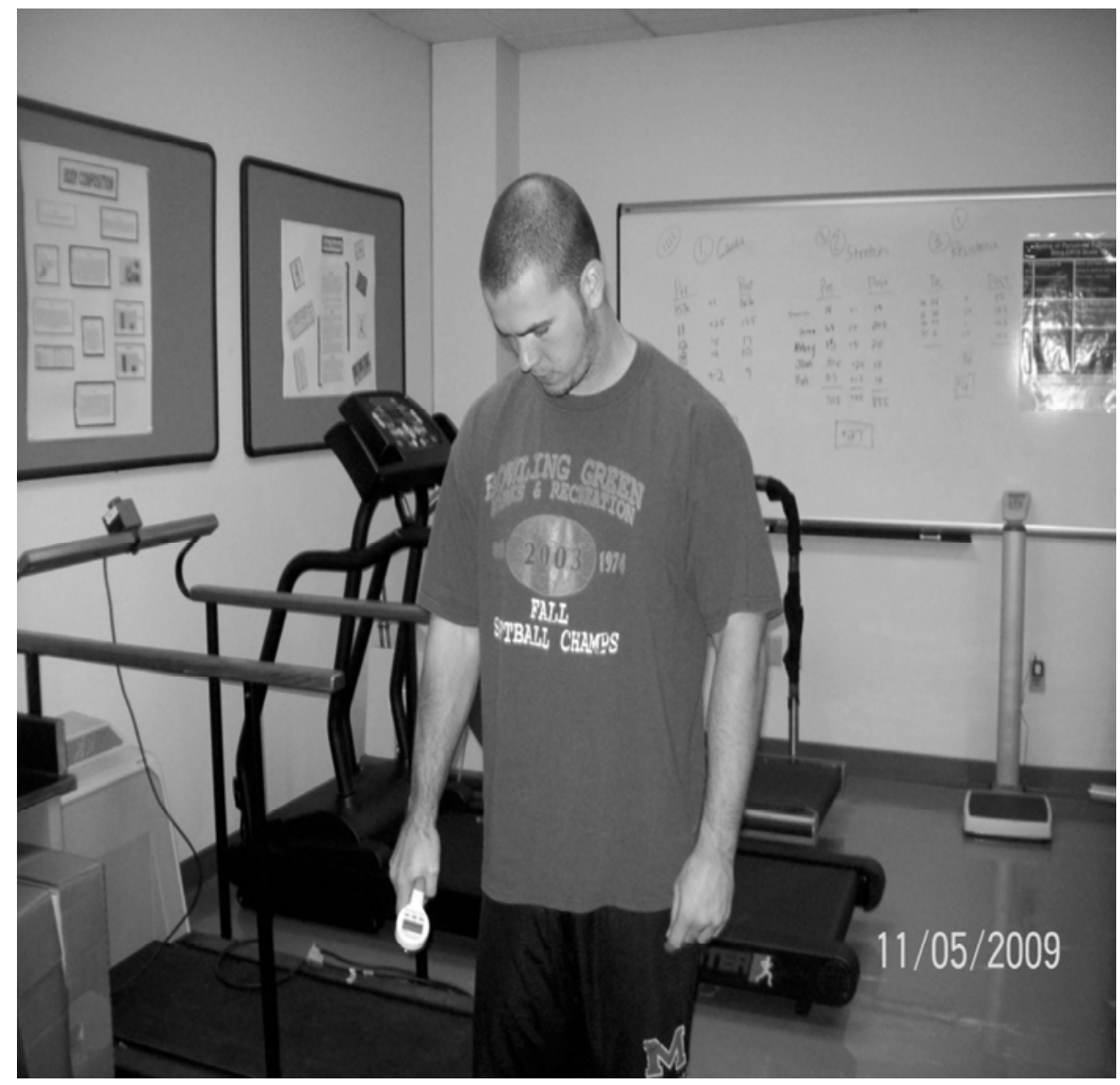

Fig. 1. Muscular Strength Assessment. 


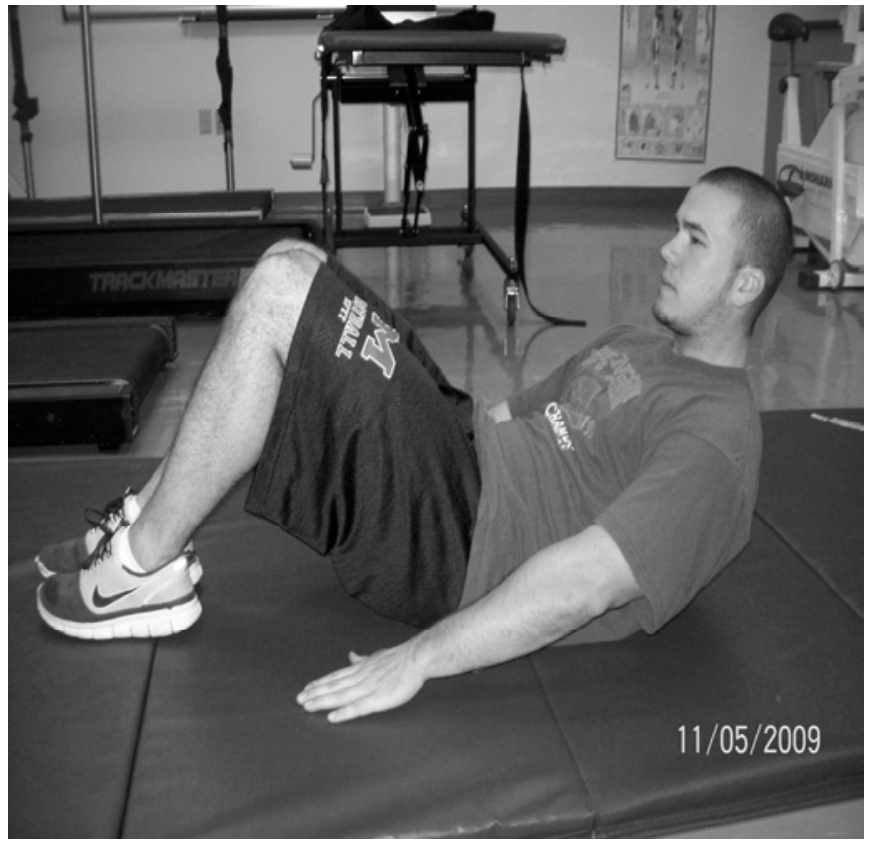

Fig. 2. Muscular Endurance Assessment.

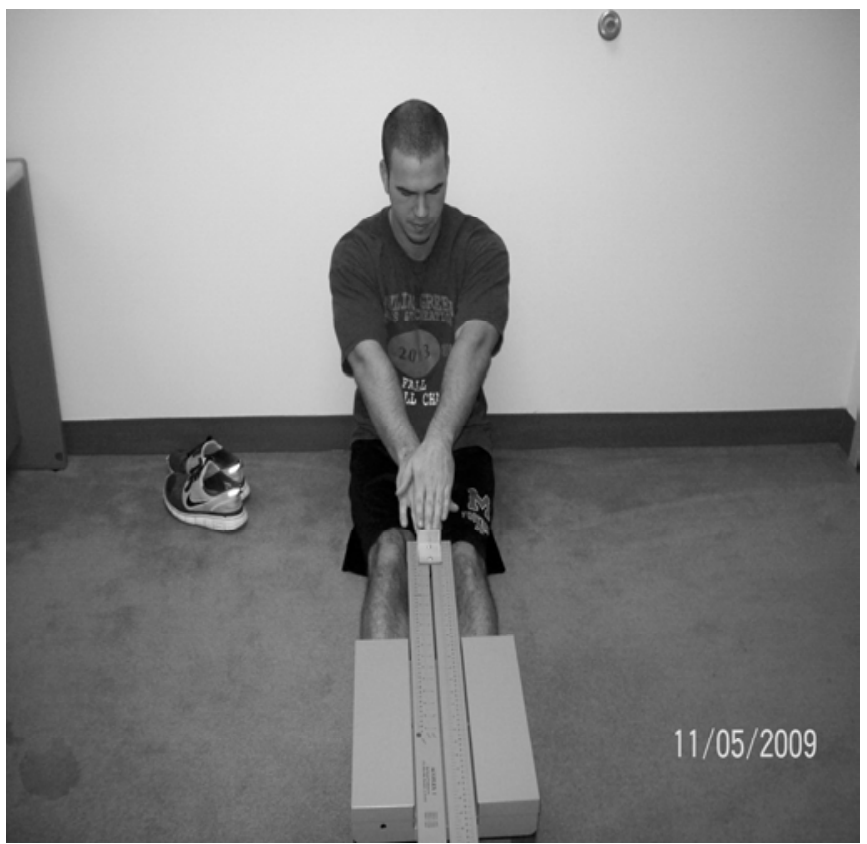

Fig. 3. Flexibility Assessment. 


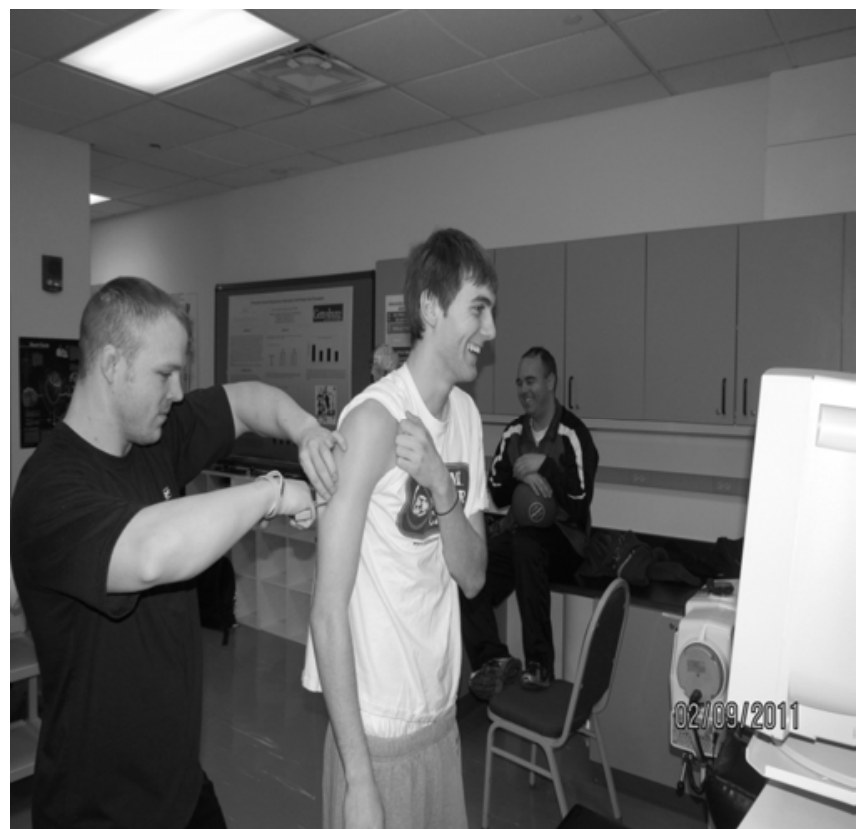

Fig. 4. Body Composition Assessment.

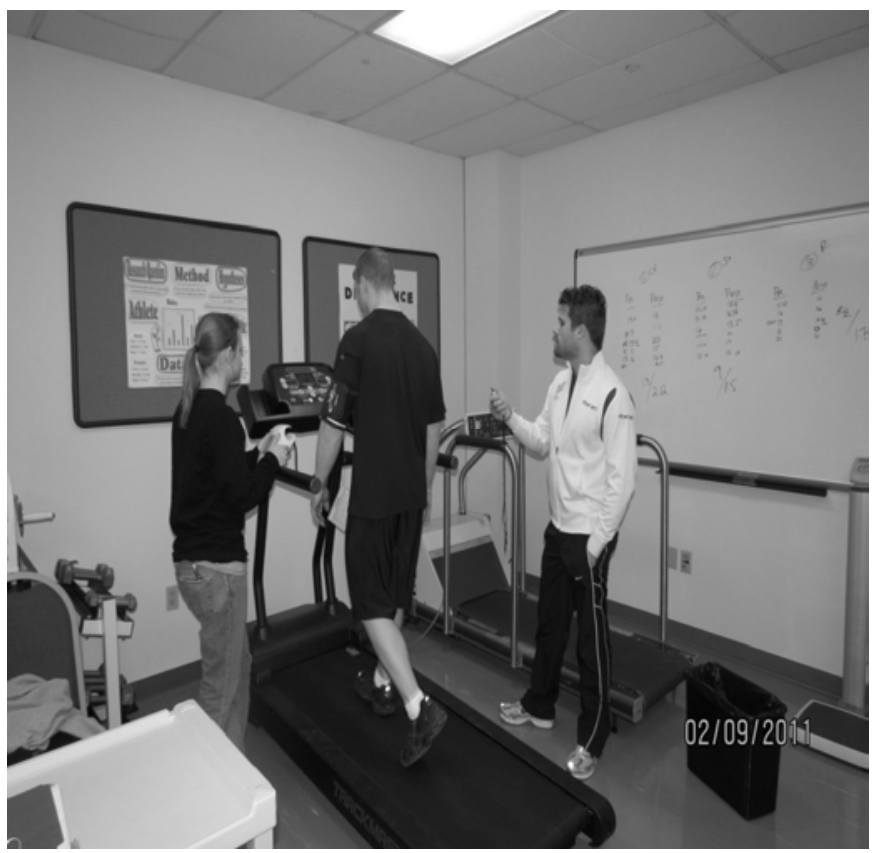

Fig. 5. Cardiovascular Endurance Assessment. 
Fitness assessments are useful to quantitatively monitor progress during exercise training. Of note, however, is the fact that cancer-specific norms have not yet been developed. Therefore, the scores received by the cancer patient during his/her fitness assessment are compared to norm charts from a healthy population. This must be taken into consideration during goal setting, particularly for those individuals who are currently undergoing treatment. Typically, for these individuals, as well as patients with recurrent disease, the goal of the exercise program should be simply to preserve function. It is important to have realistic expectations for the exercise intervention so that the patient does not become discouraged, as research indicates that adherence to an exercise intervention is a challenging task (Markes et al., 2006).

\subsubsection{Exercise prescription}

Once the fitness assessment has been completed and reviewed, the fitness trainer may design an individualized exercise prescription for the patient. An exercise prescription is a plan of fitness-related activities designed for a specific purpose. In other words, an exercise prescription is a prescription for exercise. Recommendations pertaining to the frequency, intensity, duration, mode, and progression of exercise must be addressed. Ideally, for an individual undergoing cancer treatment, the prescription will include a whole-body workout that targets all the major muscle groups. The overall goal of the exercise program should be to minimize the general de-conditioning that often results from cancer treatment so that the cancer treatments are better tolerated. In general, the exercise prescription should include a slow progression and demonstrate adaptability to changes in the patient's health status, which frequently will change from day-to-day during treatment. According to ACSM (Schmitz et al., 2010), the general objectives for exercise training among cancer survivors are as follows:

1. To regain and improve physical function, aerobic capacity, strength, and flexibility.

2. To improve body image and QOL.

3. To improve body composition.

4. To improve cardiorespiratory, endocrine, neurological, muscular, cognitive, and psychosocial outcomes.

5. Potentially, to reduce or delay recurrence or a second primary tumor.

6. To improve the ability to physically and psychologically withstand the ongoing anxiety regarding recurrence or a second primary cancer.

7. To reduce, attenuate, and prevent long-term and late effects of cancer treatment.

8. To improve the physiologic and psychological ability to withstand any current or future cancer treatments.

At present, the optimal frequency, duration, and time course of adaptation to aerobic and resistance exercise training in cancer patients are not known, although research indicates that individuals undergoing cancer therapy benefit from low-to-moderate intensity aerobic and resistance exercise (Swartz, 2009). Based on available data, Table 3 presents some general guidelines a fitness professional may follow when designing an exercise program (Schmitz et al., 2010; Physical Activities Guidelines Advisory Committee, 2008; Haskell et al., 2007; Schneider \& Carter, 2003).

Initially, intensity will depend on the patient's functional status and exercise history prior to cancer diagnosis. Typically, previously active cancer patients may continue their exercise regimen, although intensity may need to be decreased during treatment. Progression should consist of increases in frequency and duration rather than in intensity (Physical Activities 
Guidelines Committee, 2008; Schneider \& Carter, 2003). To assist in progression, patients should be reassessed approximately every 6 months (Schneider \& Carter, 2003).

\begin{tabular}{|c|l|l|l|}
\hline & \multicolumn{1}{|c|}{ Aerobic Training } & \multicolumn{1}{|c|}{ Strength Training } & \multicolumn{1}{|c|}{ Flexibility Training } \\
\hline Frequency & $3-5$ days/wk & 2-3 days/wk & 2-7 days/wk \\
\hline Intensity & $40-60 \% \mathrm{HRR}^{*}$ & $40-60 \% \mathrm{HRR}^{*}$ & $\begin{array}{l}\text { Stretch to the point } \\
\text { of mild discomfort }\end{array}$ \\
\hline Duration & $20-60 \mathrm{~min} /$ session & $\begin{array}{l}1-3 \text { sets, } 8-12 \text { reps } \\
\text { per exercise }\end{array}$ & $\begin{array}{l}\text { 10-30 seconds per } \\
\text { stretch }\end{array}$ \\
\hline Mode & $\begin{array}{l}\text { Walking, cycling, cross } \\
\text { trainers, swimming }\end{array}$ & $\begin{array}{l}\text { Free weights, } \\
\text { machines, resistance } \\
\text { bands, resistance } \\
\text { balls }\end{array}$ & Static stretching \\
\hline
\end{tabular}

${ }^{*} \mathrm{HRR}=$ Heart Rate Reserve

HRR $=[($ Maximum Heart Rate - Resting Heart Rate $) \times$ Intensity $]+$ Resting Heart Rate

Table 3. Guidelines for Designing an Exercise Prescription for Individuals Undergoing

Cancer Treatment.

\subsubsection{Supervised exercise sessions}

Once the individualized exercise prescription has been created, the patient may begin supervised training sessions with the fitness professional. Prior to each exercise session, it is advisable to assess the patient's readiness to exercise. Resting heart rate and blood pressure should be measured, and general information regarding the patient's overall health status should be obtained. Contraindications to exercise are listed in Table 4. Depending on the information attained, the exercise intervention may need to be adjusted for that day.

\begin{tabular}{|l|}
\hline Onset of nausea following exercise initiation \\
\hline Vomiting within the last 24 hours \\
\hline Leg pain \\
\hline Decreased heart rate and blood pressure with increased workload \\
\hline Chest pain \\
\hline Difficult or shallow breathing \\
\hline Unusual muscle weakness \\
\hline Numbness in the extremities \\
\hline Chemotherapy treatment within the last 24-hours \\
\hline Irregular pulse during exertion \\
\hline Disorientation and confusion \\
\hline Dizziness \\
\hline
\end{tabular}

Table 4. Contraindications to exercise in cancer patients.

Each session should begin with a 5- to 10-minute warm-up that stimulates blood flow to the working muscles. The warm-up should involve some mild stretching and light aerobic activity. During the aerobic component of exercise, it is important to frequently monitor blood pressure and heart rate. If the patient is on a medication that affects heart rate, the Borg Scale of Exertion (Borg, 1973) (Figure 6) may be used to monitor intensity. Based on 
this scale, a light-to-moderate intensity (RPE of 11 to 14) should be encouraged. If dizziness, nausea, or chest pain occurs, all exercise should be stopped. Frequent short breaks are sometimes encouraged to accommodate therapy-related fatigue. Aerobic exercise should be followed up by static stretching and range of motion exercises for all major muscle groups.

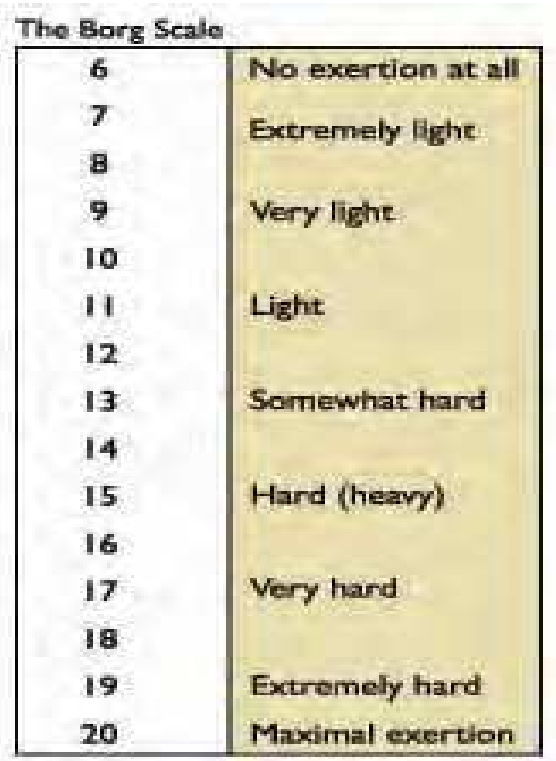

Fig. 6. The Borg Scale Rating Perception of Effort (RPE).

The type of resistance exercise performed will depend on the patient's range of motion, tissue removal, and wound healing. ACSM recommends at least 48 hours of rest between each resistance training session (Schneider \& Carter, 2003). Therefore, it may be advisable to plan a whole body approach to resistance training, where all major muscle groups are targeted in one day. If the patient is unwilling or unable to participate in traditional modes of strength training, Yoga or Pilates may serve as an alternative form of strength exercise. Sample exercises are shown in pictures below (Figures 7-10).

At the conclusion of the exercise session, the patient should perform a 5-10 minute cool down along with some mild stretching. Sample stretches are shown in the pictures below (Figures 11 and 12). A proper cool down will reduce the potential for muscle soreness, decrease post-exercise dizziness, and allow the heart rate to return to its resting state.

\subsection{Phase 2: Exercise after cancer recovery}

For patients who have completed cancer therapy, exercise is important to maintain or improve function and prevent the development of diseases associated with inactivity (i.e. diabetes, cardiovascular disease, obesity) (Swartz, 2009). The objective of exercise training during cancer recovery should be to return the patient to their former level of physical function and make exercise an integral part of everyday life. Some side effects of anticancer medications do not appear for months or years after the discontinuation of treatment, therefore it is advised to maintain contact with the patient's physician, in order to monitor 
any changes in health status. The fitness professional should follow the same general guidelines and procedures listed above when working with a cancer survivor.
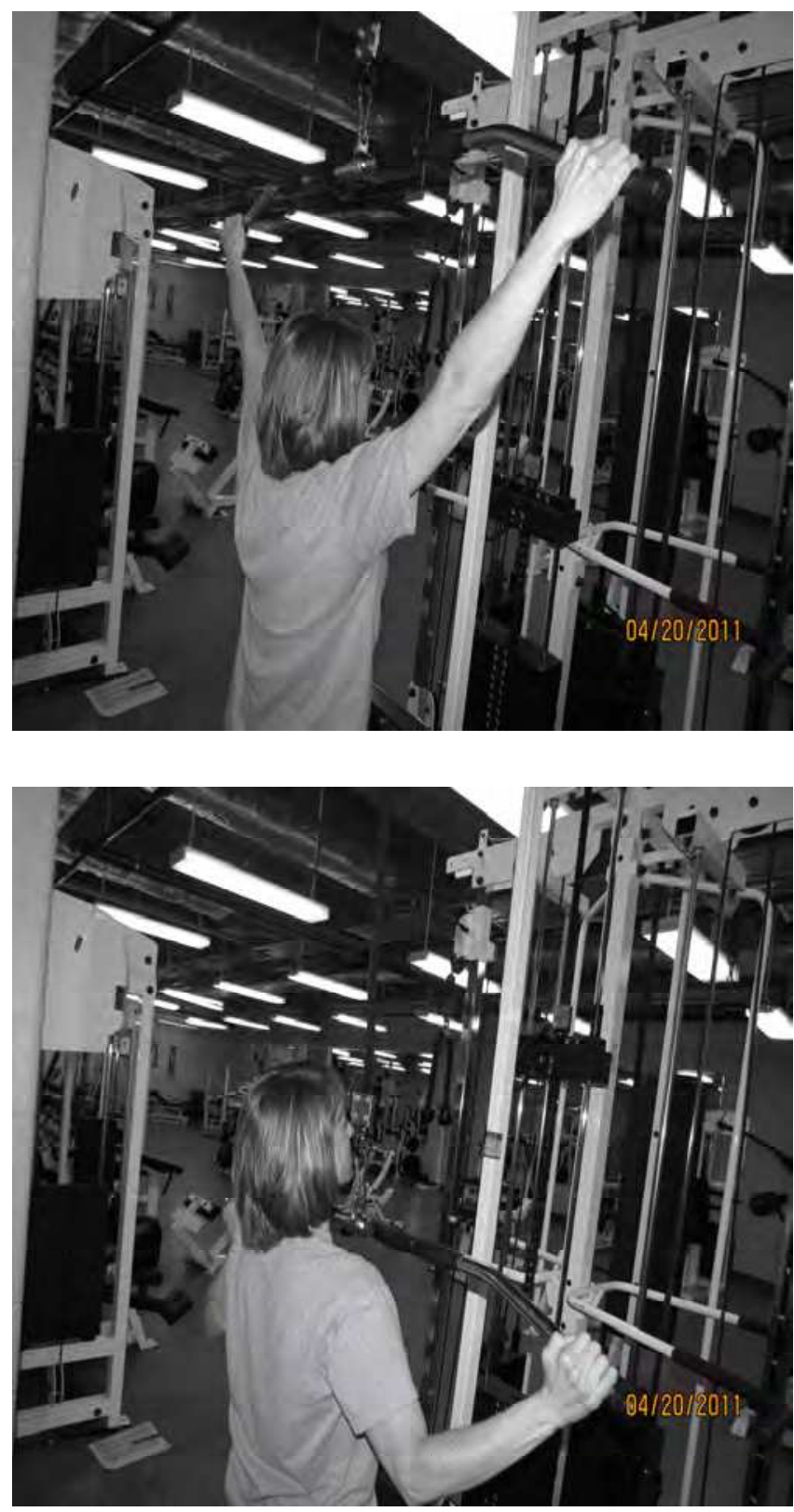

Fig. 7. Lat Pull Down. 

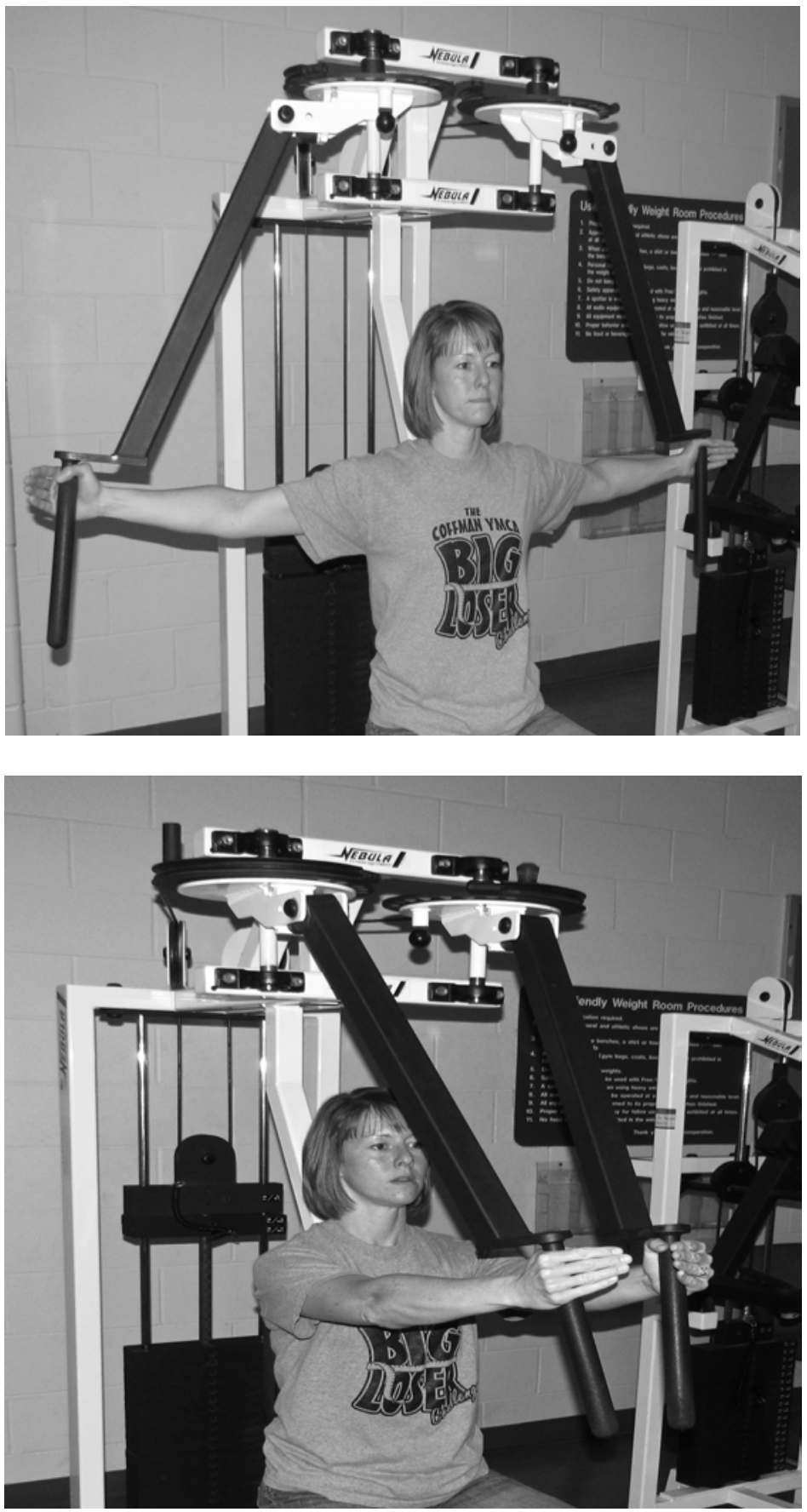

Fig. 8. Lateral Chest Press. 

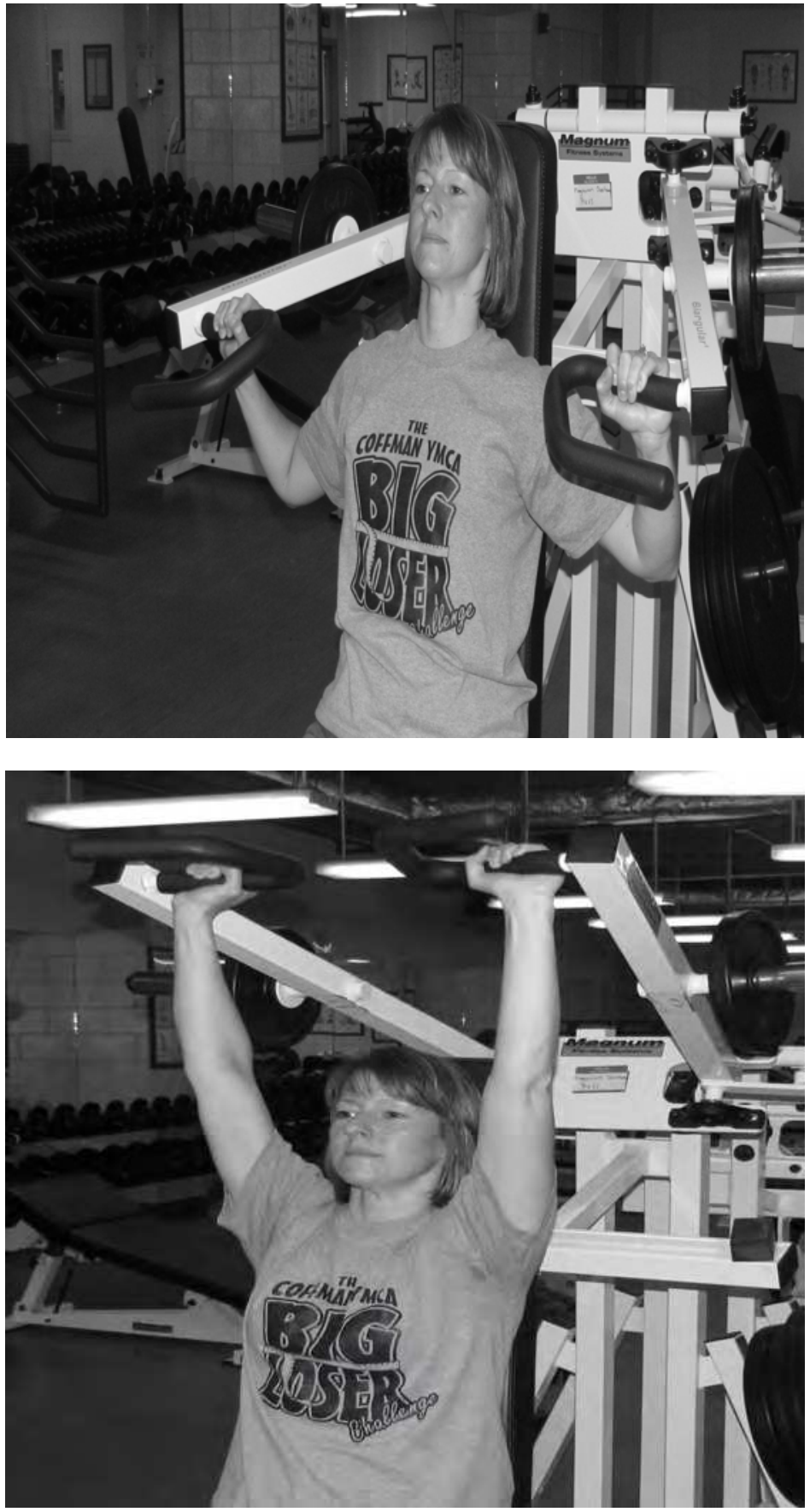

Fig. 9. Shoulder Press. 


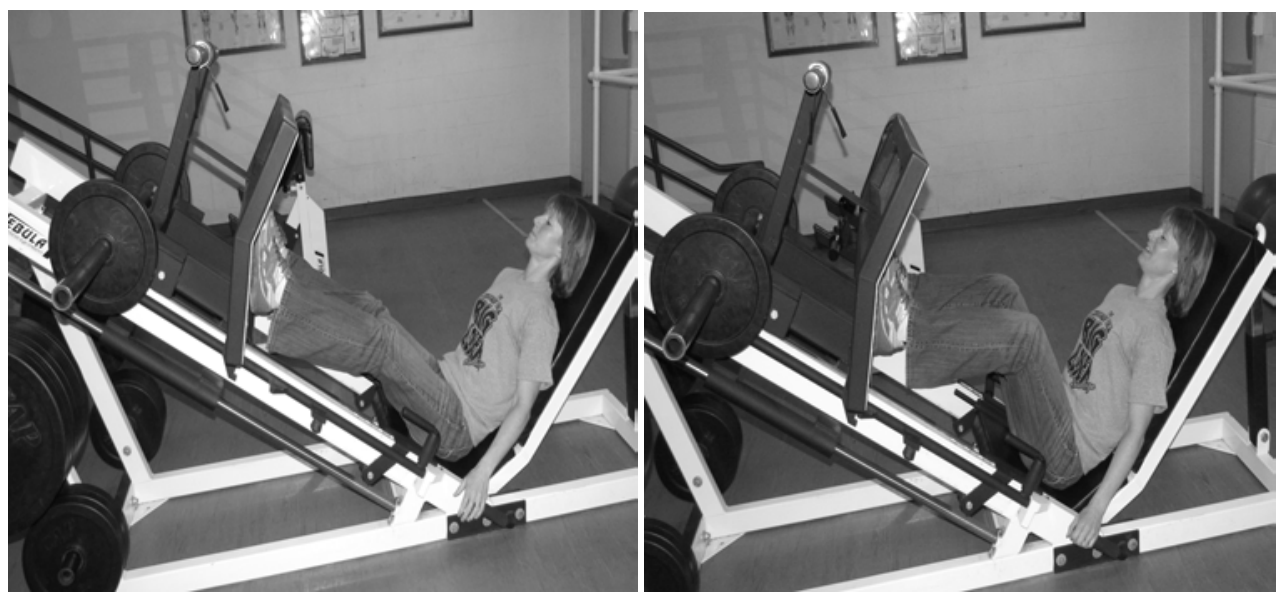

Fig. 10. Leg Press.

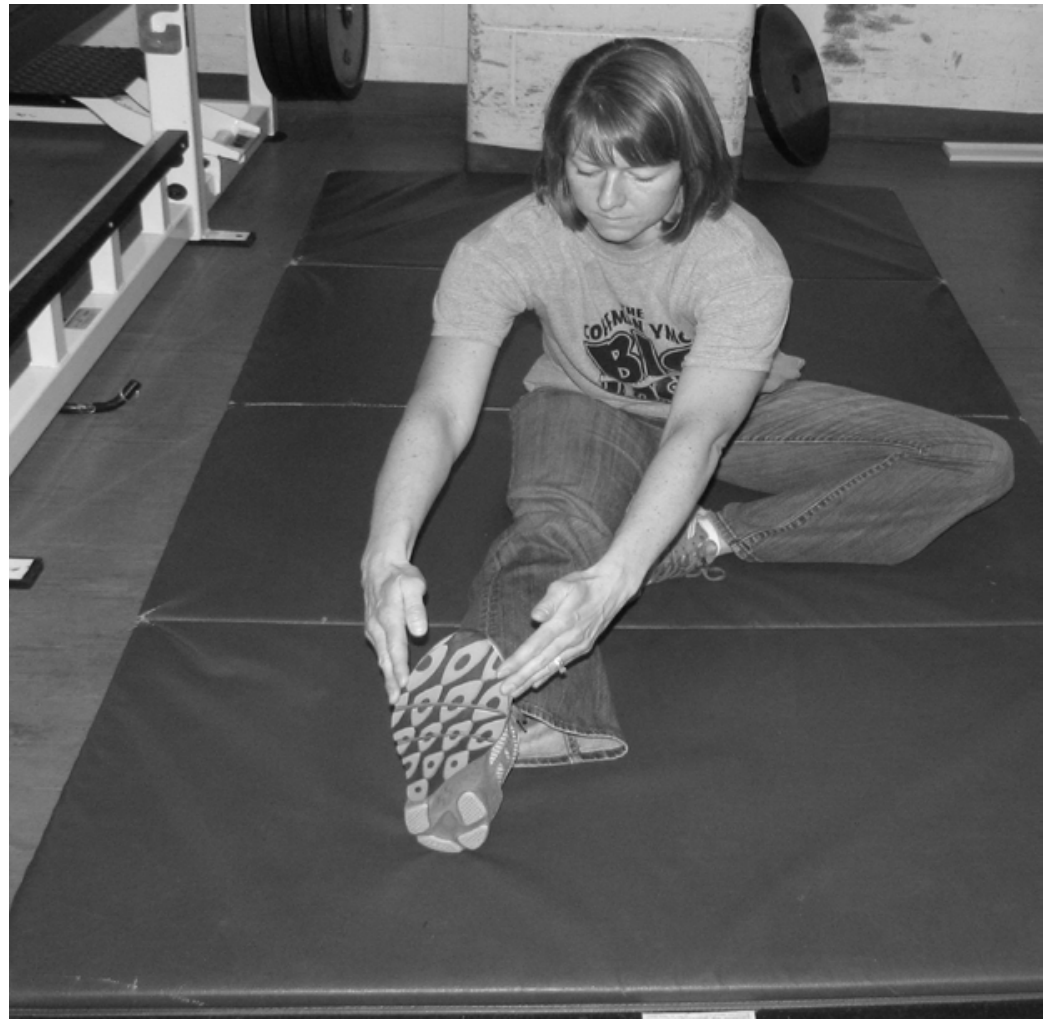

Fig. 11. Lower body stretch. 


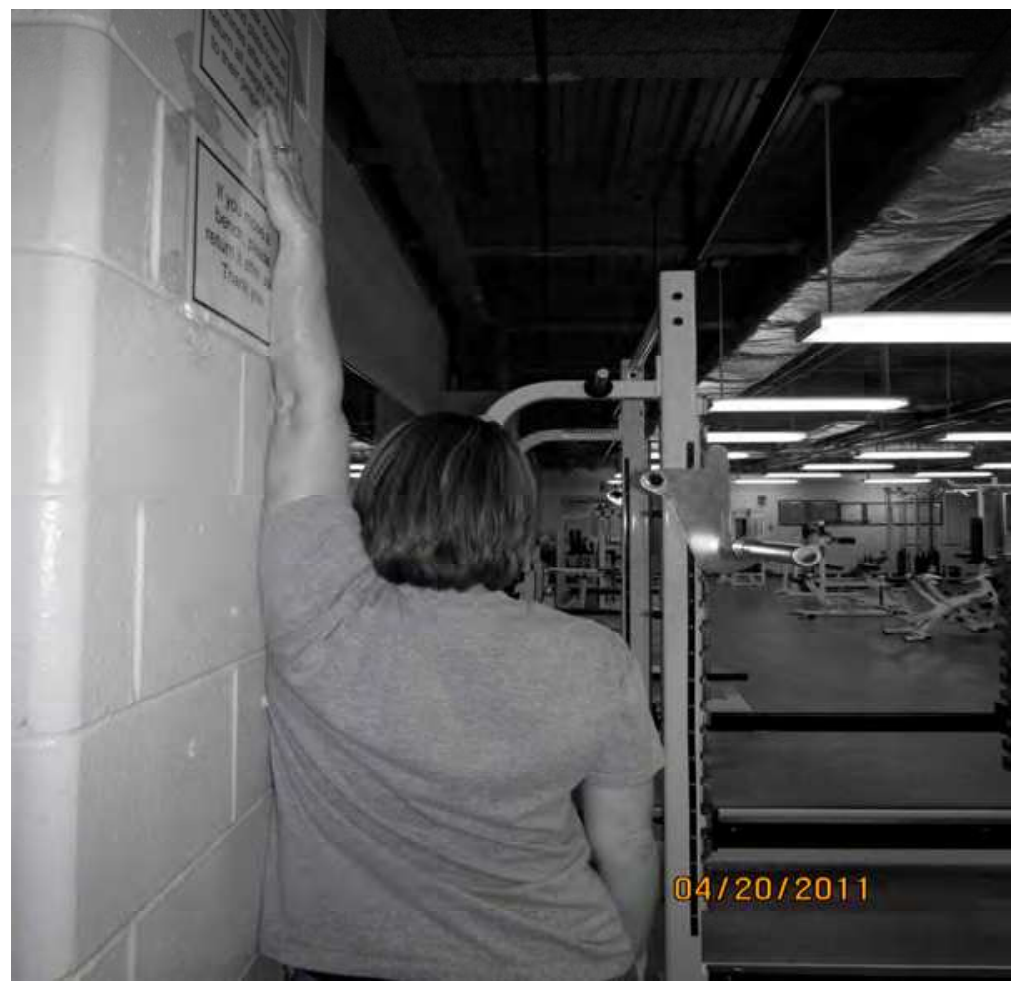

Fig. 12. Upper body stretch.

\section{Conclusion}

Two decades of research support the assertion that exercise is both safe and beneficial during cancer treatment. Most standard exercise protocols are well tolerated by patients. However, it is important that the fitness professional be aware of the specific effects of cancer and its treatments on the exercise response. Exercise prescriptions must be individualized according to the specific needs and health status of each patient. During each exercise session, modifications may need to be made to ensure patient safety, depending on the changing health of each patient. With the right program, remaining physically active during and after cancer treatment will improve the patient's muscular strength and aerobic functioning, decrease fatigue, improve QOL and have a favorable effect on anxiety.

\section{References}

Activities Guidelines Advisory Committee. (2008). Physical Activity Guidelines Advisory Committee Report. US Department of Health and Human Services, Philadelphia, PA.

American Cancer Society. (2010). Pain Control. Date of access: April 13, 2011. Available from:

http://www.cancer.org/Treatment/TreatmentsandSideEffects/PhysicalSideEffect s/Pain/PainDiary/pain-control-causes-of-cancer-pain 
American Cancer Society. (2011). Stay Healthy. Healthy living information to help you stay well. Date of access: March 24, 2011. Available from:

http://www.cancer.org/Healthy/EatHealthyGetActive/GetActive/index

American Heart Association. (2011). Physical Activity. Date of Access: April 14, 2011. Available from:

http:/ / www.americanheart.org/ presenter.jhtml?identifier $=4563$

Borg, G.A.V. (1973). Rating Perception of Effort. Lippincott, Williams, \& Wilkins, Philadelphia, PA.

Cella, D., Lai, J.S., Chang, C.H., Peterman, A., \& Slavin, M. (2002). Fatigue in cancer patients compared with fatigue in the general United States population. Cancer, 94, No. 2, pp. 528-38.

Centers for Disease Control and Prevention. (2007). Cancer survivors - United States, 2007. MMWR. Recommendations and reports : Morbidity and mortality weekly report. Recommendations and reports / Centers for Disease Control, 60,9, pp. 269-272.

Chabner, B.A., \& Longo D.L. (2010). Cancer Chemotherapy and Biotherapy (5th ed.). Lippincott Williams \& Wilkins, ISBN-10: 1605474312, Philadelphia, PA.

Cheema, B.S.B, \& Gual, C.A. (2006). Full-body exercise training improves fitness and quality of life in survivors of breast cancer. Journal of Strength and Conditioning Research, 20, No. 1, pp.14-21.

Coon, S.K. \& Coleman, E.A. (2004). Keep moving: Patients with myeloma talk about exercise and fatigue. Oncology Nursing Forum. 31, No. 6, pp. 1127-35.

Courneya, K.S. \& Friedenreich, C.M. (2007). Physical activity and cancer control. Seminars in Oncology Nursing, 23, pp. 242-52.

Courneya, K.S., Friedenreich, C.M., Quinney, H.A., Fields, A.L.A, Jones, L.W., \& Fairey A,S. (2003) A randomized trial of exercise and quality of life in colorectal cancer survivors. European Journal of Pharmacology, 12, 347-57.

Courneya, K.S., Keats, M.R., \& Turner, A.R. (2000). Physical exercise and quality of life in cancer patients following a high dose chemotherapy and autologous bone marrow transplatation. Psycho-oncology. 9, No. 2, pp. 127-36.

Courneya, K.S., Stellar, C.M., Stevinson, C., McNeely, M.L., Peddle, C.J., Friedenreich, C.M., Tankel, K., Basi, S., Chua, N., \& Mazurek, A. (2009). Randomized controlled trial of the effects of aerobic exercise on physical functioning and quality of life in lymphoma patients. Journal of Clinical Oncology, 27, No. 27, pp. 4605-12.

Courneya, K.S., Vallance, J.K.H., Jones, L.W., \& Reiman, T. (2005). Correlates of exercise interventions in non-Hodgkin's lymphoma survivors: An application of the Theory of Planned Behavior. Journal of Sport and Exercise Psychology, 27, pp. 335-49.

Damush, T., Perkins, A., \& Miller, K. (2006). The implementation of an oncologist referred, exercise self-management program for older breast cancer survivors. Psychooncology 15, No. 10, pp. 884-90.

DeVita, V.T., Hellman, S., \& Rosenberg, S.A. (2001). Cancer: Principles and Practice of Oncology (6 $6^{\text {th }}$ ed.). Vols. 1 and 2. Lippincott-Williams \& Wilkins, ISBN-10: 0781722292, Philadelphia, PA.

DeVita, V.T., Lawrence, T.S., \& Rosenberg, S.A. (2008). Supportive Care and Quality of Life. In: Cancer: Principles $\mathcal{E}$ Practice of Oncology. Vol. 2. (8th ed.). pp. 2796. Lippincott Williams \& Wilkins, ISBN-10: 9780781772075, Philadelphia, PA. 
Dimeo, F., Bertz, H., Finde, J., Fetscher, S., Mertelsmann, R., \& Kuel, J. (1996). An aerobic exercise program for patients with haematological malignancies after bone marrow transplantation. Bone Marrow Transplantation, 18, No. 6, pp. 1157-60.

Douglas, E. (2005). Exercise in cancer patients. The Physical Therapy Review, 10, pp. 71-88.

Doyle, C., Kushi, L., Byers, T., Courneya, K.S., Denmark-Wahnefried, W., Grant, B., McTiernan, A., Rock, C.L., Thompson, C., Gansler, T., \& Andrews, K.S. (2006). Nutrition and physical activity during and after cancer treatment: an American Cancer Society guide for informed choices. Cancer Journal for Clinicians, 56, No. 6, pp. 323-53.

Fischer,D.S., Knobf, M.T., \& Durivage, H.J. (2003). The Cancer Chemotherapy Handbook (6 ${ }^{\text {th }}$ ed.). Mosby, ISBN-10: 0323018904, St. Louis.

Friedenreich, C.M. \& Orenstein, M.R. (2002). Physical activity and cancer prevention: Etiologic evidence and biological mechanisms. The Journal of Nutrition, 132, pp. 5456-64.

Galvo, D.A. \& Newton, R.U. (2005). Review of exercise intervention studies in cancer patients. Journal of Clinical Oncology, 23, No. 4, 899-909.

Haran, C. \& DeVita, V. (2005). The view from the top. Cancer World, 6 (June, 2005), pp. 38-43.

Harriss, D., Cable, T., George, K., Reilly, T., Renenan, A.G., \& Haboubi, N. (2007). Physical activity before and after diagnosis of colorectal cancer. Sports Medicine, 37, No. 11, pp. 947-60.

Hartvig, P., Aulin, J., Hugerth, M., Wallenberg, S., \& Wagenius, G. (2006). Fatigue in cancer patients treatedwith cytotoxic drugs. Journal of Oncology Pharmacy Practice, 12, No. 3, pp. 155-164.

Haskell, W.L., Lee, I.M., Pate, R.R., Powell, K.E., Blair, S.N., Franklin, B.A., Macera, C.A., Heath, G.W., Thompson, P.D., \& Bauman, A. (2007). Physical activity and public health: Updated recommendation for adults from the American College of Sports Medicine and the American Heart Association. Medicine and Science in Sports and Exercise, 39, No. 8, pp. 1423-34.

Haydon, A.M., Macinnis, R, English, D, \& Giles G.G. (2006). The effect of physical activity and body size on survival after diagnosis with colorectal cancer. Gut, 55, No. 1, pp. 62-7.

Holmes, M.D., Chen, W.Y., Feskanich, D, Kroenke, C.H., \& Colditz, G.A. (2005). Physical activity and survival after breast cancer diagnosis. JAMA, 293, No. 20, pp. 2479-86.

Jones, J.M., Cheng, T., Jackman, M., Rodin, G., Walton, T., \& Catton, P. (2010). Self-efficacy, perceived preparedness, and psychological distress in women completing primary treatment for breast cancer. Journal of Psychosocial Oncology, 28, No. 3, pp. $269-90$.

Kercher, K., Fleischer, A., \& Yosipovitch, G. (2008). Lower extremity lymphedema update: pathophysiology, diagnosis, and treatment guidelines. Journal of the American Academy of Dermatology, 59, No. 2, 324-31.

Klein, M. (2009). Immunobiological and neural substrates of cancer-related neurocognitive deficits. The Neuroimmunological Basis of Behavior and Mental Disorders, 3, pp. 327-40.

Kruk, J. (2007). Physical activity in the prevention of the most frequent chronicdiseases: An analysis of the recent evidence. Asian Pacific Journal of Cancer Prevention, 8, pp.32538.

Lee, I.M. (2003). Physical activity and cancer prevention - data from epidemiologic studies. Medicine and Science in Sports and Exercise, 35, No. 11, pp. 1823-7. 
Lucia, A., Earnest, C., \& Perez M. (2003). Cancer-related fatigue: Can exercise physiology assist oncologists? The Lancet Oncology, 4, No. 10, pp. 616-25.

Markes, M., Brockow, T., \& Resch, K.L. (2006). Exercise for women receiving adjuvant therapy for breast cancer. Cochrane Database of Systematic Reviews (Online), 18, No. 4, pp. CD005001.

Martingnoni, M., Kunze, P., \& Friess, H. (2003). Cancer Cachexia. Molecular Cancer, 2, pp. 36.

Meyerhardt, J.A., Giovannucci, E.L., Holmes, M.D., Chan, A.T., Chan, J.A., Colditz, G.A., \& Fuchs C.S. (2006). Physical activity and survival after colorectal cancer diagnosis. Journal of Clinical Oncology, 24, No. 22, pp. 3527-34.

Meyerhardt, J.A., Heseltine, D., Niedzwiecki, D., Hollis, D., Saltz, L.B., Mayer, R.J., Thomas, J., Nelson, H., Whittom, R., Hantel, A., Schilsky, R.L., \& Fuchs, C.S. (2006). Impact of physical activity on cancer recurrence and survival in patients with stage III colon cancer: Findings from CALGB 89803. Journal of Clinical Oncology, 24, No. 22, pp. 3535-41.

Meyerowitz, B.E., Watkins, I.K., \& Sparks, F.C. (1983). Quality of life for breast cancer patients receiving adjuvant chemotherapy. The American Journal of Nursing, 83, No. 2, pp. 232-35.

Miles, L. (2007). Physical activity and the prevention of cancer: A review of recent findings. Nutrition Bulletin, 32, pp. 250-82.

Mock, V., Dow, K.H., Meares, C.J., Grimm, P.M., Dienemann, J.A., Haisfield-Wolfe, M.E., Quitasol, W.,

Mitchell, S., Chakravorthy, A., \& Gage, I. (2007). Effects of exercise on fatigue, physical functioning, and emotional distress during radiation therapy for breast cancer. Oncology Nursing Forum, 24, No. 6, pp. 991-1000.

Muss, H.B. (2007) Breast cancer and differential diagnosis of benign lesions. In Cecil Medicine (23rd ed.), Goldman. L., Ausiello, D., eds. Pp. 1501-1509, Saunders Elsevier, ISBN-10: 1416028056, Philadelphia, PA.

National Cancer Institute. (2009) Cancer Trends Progress Report - 2007. Date of access: March 28, 2011. Available from http:/ / progressreport.cancer.gov/ doc.asp?pid=1\&did=2007\&mid=vcol\&chid=71

National Institutes of Health. (2011). Estimates of Funding for Various Research,Condition, and Disease Categories. Date of access: March 24, 2011. Available from: http://report.nih.gov/rcdc/categories/

Pihkala, J., Happonen, J.M., Virtanen, K., Souijarvi, A., Simes, M.A., Pesonen, E., \& Saarinen U.M. (1995). Cardiopulmonary evaluation of exercise tolerance after chest irradiation and anticancer chemotherapy in children and adolescents. Pediatrics. 95, No. 5, pp. 722-26.

Pinto, B., Clark, M., Maruyama, N., \& Feder, F. (2003). Psychological and fitness changes associated with exercise participation among women with breast cancer. Psychooncology. 12, No. 2, pp. 118-26.

Pirl W.F. \& Roth, A.J. (1999). Diagnosis and treatment of depression in cancer patients. Oncology 13, No. 9, pp. 1293-1301.

Quist, M., Rorth, M., Zacho, M., Andersen, C., Moeller, T., Midtgaard, J., Adamsen, L. (2006). High-intensity resistance and cardiovascular training improve physical capacity in cancer patients undergoing chemotherapy. Scandinavian Journal of Medicine \& Science in Sports, 16, No. 5, pp. 349-57. 
Schneider, C.M., Carter, S. (2003). The role of exercise in recovery from cancer treatment. Rocky Mountain Cancer Rehabilitation Institute. ACSM Fit Society Page, 6, pp. 9.

Schneider, C.M., Dennehy, C.A., \& Carter, S.D. (2003). Exercise and Cancer Recovery. Human Kinetics, ISBN-10: 736036458, Champaign, IL.

Schmitz, K.H., Courneya, K.S., Matthews, C., Demark-Wahnefried, W., Galval, D.A., Pinto, B.M., Irwin, M.L., Wolin, K.Y., Segal, R.J., Lucia, A., Schneider, C.M., von Gruenigen, V.E., \& Schwartz, A.L. (2010). American College of Sports Medicine Roundtable on Exercise Guidelines for Cancer Survivors. Medicine and Science in Sports and Exercise, 42, No. 7, 1409-26.

Schwartz, A.I., Mori, M., Gao, R., Nail, L.M., \& King, M.E. (2001). Exercise reduced daily fatigue in women with breast cancer receiving chemotherapy. Medicine and Science in Sports and Exercise, 33, No. 5, pp. 718-23.

Segal, R., Evans, W., Johnson, D., Smith, J., Colletta, S., Gayton, J., Woodard, S., Walls, G., \& Reid, R. (2001). Structured exercise improves physical functioning in women with stages I and II breast cancer: Results of a randomized controlled trial. Journal of Clinical Oncology, 19, No. 3, pp. 657-65.

Snyder, C.C. (1986). Oncology Nursing. Little Brown, Boston.

Swartz, A.L. (2009). Cancer, In: ACSM's Exercise Management for Persons with Chronic Diseases and Disabilities (3rd ed.). Durstine, J.L., Moore, G.E., Painter, P.L., Roberts, S.O., (Eds.). pp. 211-218, Human Kinetics, ISBN-10: 0736074333, Champaign, IL.

Thorsen, L., Skovlund, E., Stromme, S.B., Hornslien, K., Dahl, A.A., \& Fossa, S.D. (2005). Effectiveness of physical activity on cardiorespiratory fitness and health-Related quality of life in young and middle-aged cancer patients after chemotherapy. Journal of Clinical Oncology, 23, No. 10, pp. 2378-88.

Watson, T. \& Mock, V. (2004). Exercise as an intervention for cancer-related fatigue. Physical Therapy, 84, No. 8, pp. 736-43.

Wiggins, M.S. \& Simonavice, E.M. (2008). Quality of life benefits: A 12-month exercise cancer recovery casestudy. KAHPERD Journal. 44, pp.16-9.

Wiggins, M.S. \& Simonavice, E.M. (2009). Quality of life benefits in cancer survivorship with supervisedexercise. Physiological Reports, 104, No. 2, 421-24.

Wiggins, M.S. \& Simonavice, E.M. (2010). Cancer prevention, aerobic capacity, and physical functioning in survivors related to physical activity: A recent review. Cancer Management and Research, 2, pp. 157-64.

Wilmore, J.H., Costill, D.L., \& Kenney, W.L. (2008). Physiology of Sport and Exercise. (4th ed.). Human Kinetics. ISBN-10: 9780736055833, Champaign, IL.

Wilson, J.K.V. (1978). Pulmonary toxicity of antineoplastic drugs. Cancer Treatment Reports, 62, No. 12 , pp. 2003-8.

World Health Organization. (2009). Geneva: The Organization; 2009. Fact sheet no. 297: Cancer. Date of Access: March 28, 2011. Available from: http://who.int/mediacentre/factsheets/fs297/en/index.html

Young-McCaughan, S., Mays, M.Z., Arzola, S.M., Yoder, LH., Dramiga, S.A., Leclerc K.M., Caton, J.R., Sheffler, R.L., \& Nowlin M.U. (2003). Change in exercise tolerance, activity and sleep patterns, and quality of life in patients with cancer participating in a structured exercise program. Oncology Nursing Forum, 30, No. 3, pp. 441-52.

Young-McCaughan, S. (2006). Exercise in the rehabilitation from cancer. Medsurg Nursing, 15, No. 6, pp. 384-88. 


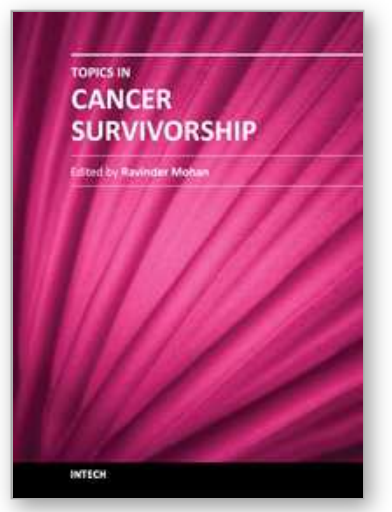

\author{
Topics in Cancer Survivorship \\ Edited by Prof. Ravinder Mohan
}

ISBN 978-953-307-894-6

Hard cover, 290 pages

Publisher InTech

Published online 27, January, 2012

Published in print edition January, 2012

Cancer is now the leading cause of death in the world. In the U.S., one in two men and one in three women will be diagnosed with a non-skin cancer in their lifetime. Cancer patients are living longer than ever before. For instance, when detected early, the five-year survival for breast cancer is $98 \%$, and it is about $84 \%$ in patients with regional disease. However, the diagnosis and treatment of cancer is very distressing. Cancer patients frequently suffer from pain, disfigurement, depression, fatigue, physical dysfunctions, frequent visits to doctors and hospitals, multiple tests and procedures with the possibility of treatment complications, and the financial impact of the diagnosis on their life. This book presents a number of ways that can help cancer patients to look, feel and become healthier, take care of specific symptoms such as hair loss, arm swelling, and shortness of breath, and improve their intimacy, sexuality, and fertility.

\title{
How to reference
}

In order to correctly reference this scholarly work, feel free to copy and paste the following:

Karen Y. Wonders (2012). The Role of Exercise in Cancer Survivorship, Topics in Cancer Survivorship, Prof. Ravinder Mohan (Ed.), ISBN: 978-953-307-894-6, InTech, Available from:

http://www.intechopen.com/books/topics-in-cancer-survivorship/the-role-of-exercise-in-cancer-survivorship

\section{INTECH}

open science | open minds

\section{InTech Europe}

University Campus STeP Ri

Slavka Krautzeka 83/A

51000 Rijeka, Croatia

Phone: +385 (51) 770447

Fax: +385 (51) 686166

www.intechopen.com

\section{InTech China}

Unit 405, Office Block, Hotel Equatorial Shanghai

No.65, Yan An Road (West), Shanghai, 200040, China

中国上海市延安西路65号上海国际贵都大饭店办公楼405单元

Phone: +86-21-62489820

Fax: +86-21-62489821 
(C) 2012 The Author(s). Licensee IntechOpen. This is an open access article distributed under the terms of the Creative Commons Attribution 3.0 License, which permits unrestricted use, distribution, and reproduction in any medium, provided the original work is properly cited. 